\title{
Comparison of Course Support Environments: Commercial Versus Open Source Software
}

\author{
Andreas VEGLIS \\ Media Informatics Lab., Department of Journalism \& Mass Communication \\ Aristotle University of Thessaloniki, 54006, Thessaloniki, Greece \\ e-mail:veglis@jour.auth.gr
}

Received: February 2005

\begin{abstract}
Course-support environments are an important technical development relating to computer communications in education that involves the linking of a web-compliant user interface and web-compliant tools and applets with an underlying database. This paper presents a comparison among three different course support environments. One of them is a commercial product and the other two are open source software. The comparison includes various features from the student, and the instructor point of view.
\end{abstract}

Key words: course-support environment, open source software.

\section{Introduction}

The information age has created many challenges for the traditional established educational institutions. The Internet is the dominant powerful tool for information exchange and communication. The educational sector is without doubt a major market for computer communications applications and services (Collis, 1999). The most dominant form of computer-aided communication is the World-Wide-Web (WWW), or simply the web. The use of the web has been adopted into every aspect of the educational life and each educational activity seems to be covered by a web-enhanced teaching system (Azuma, 1999; Das et al., 1999; Kochikar and Yegneshwar, 2000; Margi et al., 2000; Ward and Newlands, 1998). Well-designed web-based teaching tools can significantly enhance student learning, while decreasing the time spent in traditional classroom lectures (McCreanor, 2000).

Web-based educational systems are asynchronous, that is, they do not require simultaneous presence of instructor and students. Already prepared lectures are available via the Internet through web browsers. The front-ends are most often designed in HTML, enriched by Java, JavaScript, or Dynamic HTML. The web enables worldwide access independent of time and location. Using such systems does not require expensive equipment. A personal computer, nearly any operating system, a web browser, a modem, and a telephone connection enable entrance to the web and thus to web-based educational systems (Ausserhofer, 1999). While web-based teaching tools are commonly used in dis- 
tance learning applications, they also provide an opportunity to significantly enhance on-campus learning (McCreanor, 2000; Ausserhofer, 1999).

An important technical development relating to computer communications in education involves the linking of a web-compliant (i.e., accessible via a web browser) user interface and web-compliant tools and applets with an underlying database. Thus, a new type of system called course-support environment appeared (Collis, 1999; Copinga et al., 2000). It is worth mentioning that many researchers use the term virtual learning environments, as an umbrella term that covers different kinds of learning systems.

Since the beginning of 1998, the Media Informatics Laboratory of the Department of Journalism \& Mass Communication (J\&MC), at the Aristotle University of Thessaloniki (AUTh), Greece, started to develop and publish material on the web for its conventional courses (Veglis, 2000). Initially we have developed a course support environment with the help of commercial application that creates and manages web sites. This solution gave us a lot of experience about designing course support environments. Results of our effort were published in several papers (Veglis, 2002; Veglis and Barbargires, 2001; Veglis and Barbargires, 2003; Veglis and Pomportsis, 2004). But of course this solution had many limitations. Two years ago the Aristotle University of Thessaloniki has purchased and installed the commercially software tool, namely the Blackboard Learning System (http://www. blackborad.com). Thus we were able to transfer and enrich our course support environment to this new platform that offers us many new possibilities (https://blackboard.lib.auth.gr).

Other greek universities and educational networks have implemented different approaches. They have adopted open source software and customized them to meet their demands. More precisely the Greek University Network (http: / www. gunet.gr) has developed E-class (http: //eclass . gunet. gr) that is based on Claroline (http://www . claroline.net). This platform was adopted by many greek universities, for example University of Macedonia (http://www.uom.gr) which developed Compus (http:// compus .uom.gr) and also the university of Patras (http://www .upatras.gr) which developed an e-class site (http://eclass.upatras.gr/). One of the departments of the National Technical University of Athens (http://www.ntua.gr) chose Moodle (http: / /www . moodle. org) for the development of its course support environment (http://galois.medialab.ntua.gr/ecourses/).

This paper presents a comparison among the three different course support environments. One of them is a commercial product and the other two are open source software. The comparison includes various features from the student, the tutor and the administrator point of view. The rest of the paper is organized as follows: The course support environments are discussed in Section 2. The three course support environments under investigation are briefly presented in Section 3. Section 4 includes the comparison of the three environments. Concluding remarks and future extension of this work can be found in Section 5. 


\section{Course Support Environments}

\subsection{Overview}

In a course-support environment a database is integrated with web-based tools and applications, and used to generate a course-support environment accessed via a standard web browser. In its simplest form, a course-support environment is a web site that accompanies an existing course and contains some information about the course. The purpose of such sites is to enrich or increase the efficiency of some aspects of course participation, and/or make some aspects of course participation more flexible to better meet the needs of individual students. Flexibility can also allow the extension of traditional courses to nontraditional audiences, including those who could be described as distance-education students (Collis, 1999). Course-support sites can be created and maintained by the individual instructor, but increasingly such sites are maintained as part of an integrated system serving an entire department or faculty (Remmers and Collis, 2000).

It must be noted that the use of a course support environments does not exclude faceto-face contact between the instructor and the student, as well as between the students. These activities are considered to be not-to-be neglected instructional activities, even when the web is extensively used (McCreanor, 2000). Web-based course materials can be exploited to prime students for classroom lectures or laboratory practice, or even to make classroom time available for alternative learning activities.

\subsection{Advantages}

Course support environments systems offer various advantages (Veglis, 2002):

$\triangleright$ Asynchronous communication. Students can exchange ideas, ask questions, and even give responses using threaded discussions.

$\triangleright$ Synchronous communication. Students can coordinate their group work through real-time chat.

$\triangleright$ Assessment tools. Web courses include tests, quizzes, and even surveys. Students receive immediate feedback, and instructors save time in grading.

$\triangleright$ Collaborative work groups. Instructors can create online work groups specific to each class's needs, allowing access only to the students in the group. This keeps students' work secure and lets instructors monitor each group's progress.

$\triangleright$ Content creation. Instructors can post online their goals and objectives, course description, syllabi, reading lists, and assignments and give their students 24-hour access to needed materials.

$\triangleright$ Messaging system. Instructors can communicate regularly with individual students without requiring office appointments.

$\triangleright$ Online file exchange. Instructors can collect students' written assignments online. Students can place their work in a drop box for instructors to pick up at their convenience.

$\triangleright$ User tracking. Instructors can check how often each student accesses the web course. 


\subsection{Disadvantages}

There are several ways to produce such kind of environment. Several commercially available software tools make it easier to design, run and manage course support environments. Although most require a little knowledge of hypertext markup language, not much programming or other technical experience is needed.

Typically, course support environment platforms permit students to $\log$ on securely using a standard browser. In most cases, they include a database-centered syllabus with links to internal or external web pages; on time-monitored testing; discussion groups; and e-mail.

The use of course support environments has many problems. Let us discuss some of these problems:

$\triangleright$ Support of greek or other languages. This problem is very important. Although the content of the environment is in greek language the interface is in english. This is not very convenient especially for students who are not familiar with the English language. Although most students in Greece possess basic understanding of English language, the situation is different as we move on to older student.

$\triangleright$ The installation and administration of such an environment requires an experienced administrator, not to mention technical support.

$\triangleright$ Most of these packages require a designer to construct each course.

Although the idea of group working for implementing and using the course support environment (administrator, designer, tutor,) appears to promote cooperation, this model is not always suitable. This is obvious especially in the case of small university departments with limited human resources. In this case flexible solutions are required.

\section{Platforms}

\subsection{Blackboard Learning System}

Blackboard Learning System has been designed, since its inception, for institutions dedicated to teaching and learning. Blackboard technology and resources power the online, web-enhanced, or hybrid education programs at more than 2,000 academic institutions. Whether the institution is a research university, community college, high school, or virtual MBA program, the Blackboard Learning System offers a proven solution to meet an institution's needs (Yaskin, 2001; Blackboard official site).

The Blackboard Learning System features an award-winning environment for online teaching and learning and is designed to complement traditional instruction or power pure distance learning through the following utilities (Yaskin, 2001):

\footnotetext{
$\triangleright$ content management and content sharing;

$\triangleright$ assessment management;

$\triangleright$ gradebook and assignment management;

$\triangleright$ collaboration and communication;
} 
$\triangleright$ student and instructor portfolio management.

System administrators and decision-makers at organizations running the Blackboard Learning System must continually plan for an ever-increasing number of users, depth of usage, and overall load on their implementation. Through the following enterprise functions and capabilities, the Blackboard Learning System provides a flexible environment for system administration that greatly facilitates success planning and management (Yaskin, 2001):

$\triangleright$ data management for student information, identity management and authentication systems;

$\triangleright$ system management utilities;

$\triangleright$ standards, policies, and management for online courses;

$\triangleright$ branding, system configuration and design

$\triangleright$ communications and calendaring functions.

The Blackboard Learning System has been architected to deliver a responsive, highly scalable system that allows for minimal downtime and, when necessary, speedy and systematic recoveries. Designed to support a wide array of configurations, ranging from a single server to a farm of application and database servers, the Blackboard Learning System features a modular architecture that can meet a diverse set of deployment and configuration parameters.

The Blackboard platform has been in use in the Aristotle University of Thessaloniki since 2003. Currently the platform includes 163 courses but only 53 of them are active. 91 professors are using the system and 1112 students are active users. The system accepts approximately 1414 hits per day.

\subsection{Moodle}

Moodle is a course management system (CMS) - a software package designed to help educators create quality online courses. The software is used all over the world by universities, schools, companies and independent teachers. One of the main advantages of Moodle over other systems is a strong grounding in social constructionist pedagogy (Moodle official site).

The word Moodle was originally an acronym for Modular Object-Oriented Dynamic Learning Environment, which is mostly useful to programmers and education theorists. It's also a verb that describes the process of lazily meandering through something, doing things as it occurs to you to do them, an enjoyable tinkering that often leads to insight and creativity. As such it applies both to the way Moodle was developed, and to the way a student or teacher might approach studying or teaching an online course.

Moodle is Open Source software, which means you are free to download it, use it, modify it and even distribute it (under the terms of the GNU General Public License). Moodle runs without modification on Unix, Linux, Windows, Mac OS X, Netware and any other system that supports PHP, including most webhost providers. Data is stored in a single database: MySQL and PostgreSQL are best supported, but it can also be used with Oracle, Access, Interbase, ODBC and others. Moodle has 50 language packs, including: 
Arabic, Catalan, Chinese (simplified and traditional), Czech, Danish, Dutch, English (UK and US versions), Finnish, French (France and Canada versions), German, Greek, Hungarian, Indonesian, Italian, Japanese, Maori, Norwegian, Polish, Portuguese (Portugal and Brazil), Romanian, Russian, Slovak, Spanish, Swedish, Thai and Turkish. Currently there are 2596 sites from 109 countries who have registered.

An important feature of the Moodle project is the moodle.org web site (http: / / www . moodle.org), which provides a central point for information, discussion and collaboration among Moodle users, who include system administrators, teachers, researchers, instructional designers and of course, developers. In 2003, the company moodle.com was launched to provide additional commercial support for those who need it, as well as managed hosting, consulting and other services.

\subsection{Claroline}

Claroline is an Open Source software based on PHP/MySQL. It's a collaborative learning environment allowing teachers or education institutions to create and administer courses through the web. The system provides group management, forums, document repositories, calendar, chat, assignment areas, links, user profile administration on a single and highly integrated package. Claroline is translated in 28 languages and used by hundreds of institutions around world (Claroline official site).

The software was initially started by the University of Louvain (Belgium) and released under Open Source license (GPL). A community of developers around the world has since contributed to its development. Downloading and using Claroline is completely free of charge.

Claroline has been developed by an international network of teachers and developers scattered around the world. It recycles entire programs or pieces of code found in the vast library of the GPL Open Source internet mediated community. Today 370 organizations are using Claroline from 57 countries around the world (Claroline official site).

As we have mentioned in the introduction, the University of Macedonia has developed Compus (Course management Platform for Universities). The system today includes more than 200 courses and 2000 students.

\section{Comparison}

In this section we compare the tree course support environments that were presented above. The comparison is organized in three sections: Student tools, Instructor tools, and technical specifications.

\subsection{General Characteristics}

In this study we compare two open source products with one commercial product. So in the case of cost we can not make any comparison. We must also mention that the open source products include interfaces in greek language. Although Blackboard was expected to support a greek interface last summer, that did not happen. 


\subsection{Student Tools}

The student tools can be organized in communication tools, productivity tools, and student involvement tools (EduTools) (see Table 1). The communication tools include discussion forums, file exchange, internal e-mail, online journal/notes, support of real time chat, video services and whiteboard. As we can see from Table 1 the commercial product supports all the above mentioned tools. The open source products do not support video services and whiteboard. Although the lack of video services is not so crucial if we take into account the lack of broadband connection in Greece, the whiteboard is considered to be a useful tool. Blackboard supports a whiteboard that can have multiple instances in the same course and can include mathematical symbols, images, and PowerPoint uploading. It also supports group web browsing. Another useful characteristic is that Blackboard can archive a recording of whiteboard sessions for future viewing.

The productivity tools include Calendar/Progress Review, Orientation/Help, Searching with in course, and offline work. Blackboard and Moodle support almost all the above tools. Claroline supports only the first tool. Nevertheless Blackboard offers more customized tools and we must stress the support of offline work. Instructors can publish course content on a CD-ROM that can be linked to dynamically from within the online

Table 1

Student tools

\begin{tabular}{lccc}
\hline & Blackboard & Claroline & Moodle \\
\hline & Communication Tools & & \\
\hline Discussion Forums & $\sqrt{ }$ & $\sqrt{ }$ & $\sqrt{ }$ \\
File Exchange & $\sqrt{ }$ & $\sqrt{ }$ & $\sqrt{ }$ \\
Internal Email & $\sqrt{ }$ & $\sqrt{ }$ & $\sqrt{ }$ \\
Online Journal/ Notes & $\sqrt{ }$ & $\times$ & $\sqrt{ }$ \\
Real-time Chat & $\sqrt{ }$ & $\sqrt{ }$ & $\sqrt{ }$ \\
Video Services & $\sqrt{ }$ & $\times$ & $\times$ \\
Whiteboard & $\sqrt{ }$ & $\times$ & $\times$ \\
\hline & Productivity Tools & & \\
\hline Calendar/Progress Review & $\sqrt{ }$ & $\sqrt{ }$ & $\sqrt{ }$ \\
Orientation/Help & $\sqrt{ }$ & $\times$ & $\sqrt{ }$ \\
Searching Within Course & $\sqrt{ }$ & $\times$ & $\times$ \\
Offline Work & $\sqrt{ }$ & $\times$ & \\
\hline & Student Involvement Tools & & $\sqrt{ }$ \\
\hline Groupwork & $\sqrt{ }$ & $\sqrt{ }$ & $\times$ \\
Self-assessment & $\sqrt{ }$ & $\sqrt{ }$ & $\sqrt{ }$ \\
Student Community Building & $\sqrt{ }$ & & \\
Student Portfolios & & $\sqrt{ }$ & \\
\hline
\end{tabular}


course or viewed offline. In that way the system is able to support students that do not have internet connection at home.

Finally the student involvement tools include groupwork, self assessment, student community building and student portfolios. The open source products do not to support student community but that is not considered to be a crucial factor.

\subsection{Instructor Tools}

The instructor tools can be organized in course delivery tools and curriculum design (EduTools) (see Table 2). The course delivery tools include automated testing and scoring, course management, instructor helpdesk, online grading tools and student tracking. In all three platforms instructors can get reports showing the number of times and date on which each student accessed course content, discussion forums and assignments. They can also create automatically scored multiple choice, multiple answer, fill-in-the-blank and matching questions. Questions can contain images. Instructors can create personal test banks. The systems can randomize the questions in a test. Blackboard and Moodle support all course delivery tools. Claroline lacks support for course management and online grading. Both these tools are judged to be very helpful for the instructor. Course management tools allow instructors to control the progression of an online class through the course material. In online grading instructors can mark assignments and short answer tests online. They can also add the grades for offline assignments to the online gradebook. They can view grades in the gradebook by assignment, by student, and for all students on all assignments.

Table 2

Instructor tools

\begin{tabular}{lccc}
\hline & Blackboard & Claroline & Moodle \\
\hline & Course Delivery Tools & & \\
\hline Automated Testing and Scoring & $\sqrt{ }$ & $\sqrt{ }$ & $\sqrt{ }$ \\
Course Management & $\sqrt{ }$ & $\times$ & $\sqrt{ }$ \\
Instructor Helpdesk & $\sqrt{ }$ & $\sqrt{ }$ & $\sqrt{ }$ \\
Online Grading Tools & $\sqrt{ }$ & $\sqrt{ }$ & \\
Student Tracking & $\sqrt{ }$ & & $\times$ \\
& Curriculum Design & $\times$ & $\sqrt{ }$ \\
& $\sqrt{ }$ & $\sqrt{ }$ & $\sqrt{ }$ \\
Content Sharing/ Reuse & $\sqrt{ }$ & $\sqrt{ }$ \\
Interoperability & $\sqrt{ }$ & $\times$ & $\sqrt{ }$ \\
Course Templates & $\times$ & $\times$ & $\sqrt{ }$ \\
Curriculum Management & $\sqrt{ }$ & $\times$ & \\
Customized Look and Feel & $\sqrt{ }$ & & \\
Instructional Design Tools & & & \\
\hline
\end{tabular}


The curriculum design tools include content sharing/reuse, interoperability, course templates, curriculum management, customized look and feel, and instructional design tools. Only blackboard supports content sharing /reuse and none of the platforms offers curriculum management. Content sharing/reuse enables specific content created for one course to be conveniently shared with another instructor teaching a different course perhaps even at a different institution. Curriculum management provides students with customized programs or activities based on prerequisites, prior work, or results of testing. All platforms seem to comply with the existing e-learning standards/specifications (IMS, SCORM, etc.), thus supporting interoperability and permitting the migration (with some minor modifications) from one platform to another.

Instructors in Blackboard and Moodle can create both linear and nonlinear learning sequences using a content library and they can apply their own institutional images, headers and footers across all courses. Instructors can also change the navigation icons and color schemes and the order and name of menu items for a course. Claroline does not support customized look and feel of the course and instructional design tools. Based on the above we can conclude that Claroline is the platform with the least instructor tools.

Table 3

Technical specifications

\begin{tabular}{|c|c|c|c|}
\hline & Blackboard & Claroline & Moodle \\
\hline $\begin{array}{l}\text { Client } \\
\text { Browser } \\
\text { Required }\end{array}$ & $\begin{array}{l}\text { Internet Explorer } 5.5+\text {, } \\
\text { Netscape } 4.78+\text {. }\end{array}$ & $\begin{array}{l}\text { The software supports any } \\
\text { browser type or version. }\end{array}$ & $\begin{array}{l}\text { The software supports } \\
\text { any browser supporting } \\
\text { HTML } 3 \text { or higher and } \\
\text { uses cascading style sheets } \\
\text { (CSS) in browsers that } \\
\text { support CSS. }\end{array}$ \\
\hline $\begin{array}{l}\text { Database } \\
\text { Requirements }\end{array}$ & $\begin{array}{l}\text { SQL Server } 2000 \text { on } \\
\text { Windows } 2000 \text { Server, } \\
\text { or Oracle } 8 \text { on Solaris or } \\
\text { MySQL databases. }\end{array}$ & MySQL database. & $\begin{array}{l}\text { MySQL or PostgreSQL } \\
\text { databases. }\end{array}$ \\
\hline $\begin{array}{l}\text { Server } \\
\text { Software }\end{array}$ & $\begin{array}{l}\text { Apache web server or } \\
\text { Microsoft Internet Infor- } \\
\text { mation Server (IIS). }\end{array}$ & $\begin{array}{l}\text { PHP 4.x, MySQL, and } \\
\text { Apache web server soft- } \\
\text { ware. }\end{array}$ & $\begin{array}{l}\text { PHP } 4.1 .0 \text { or later, } \\
\text { MySQL (or PostgreSQL), } \\
\text { Apache web server. }\end{array}$ \\
\hline UNIX Server & $\begin{array}{l}\text { Solaris } 2.8 \text { and Red Hat } \\
\text { Linux } 6.2 . \text { Suggested } \\
\text { hardware recommenda- } \\
\text { tions are two Ultrasparc } \\
\text { II, } 450 \mathrm{Mhz}, 2 \text { GB RAM. }\end{array}$ & $\begin{array}{l}\text { The software is available } \\
\text { for most versions of Unix. }\end{array}$ & $\begin{array}{l}\text { The software is available } \\
\text { for most variants of Linux } \\
\text { or Unix. }\end{array}$ \\
\hline $\begin{array}{l}\text { Windows } \\
\text { Server }\end{array}$ & $\begin{array}{l}\text { Windows NT, } 4.0 \text {, } \\
\text { Windows } 2000 \text { Server, } \\
\text { or Advanced Server. } \\
\text { Suggested hardware } \\
\text { recommendations are } 2 \\
\text { Pentium III, } 800 \mathrm{MHz} \\
\text { CPUs, } 2 \text { GB RAM. }\end{array}$ & $\begin{array}{l}\text { The software is available } \\
\text { for a variety of Windows } \\
\text { web servers. }\end{array}$ & $\begin{array}{l}\text { The software is available } \\
\text { for a variety of Windows } \\
\text { web servers. }\end{array}$ \\
\hline
\end{tabular}




\subsection{Technical Specifications}

The technical specifications of the three platforms are included in Table 3. All platforms can be accessed with standard browsers and can be installed on Windows and Unix servers. They do not require high end servers but their performance depend on the number of courses and users they serve.

\section{Conclusion and Future Work}

One commercial software and two open source software for course support environment have been presented and compared. Based on the findings presented in the previous section we can conclude that Blackboard is a more complete product that covers all the need of the education community. Blackboard was evaluated first as far as student and instructor tools are concerned. On the other hand its cost is high and it does not support greek language interface. As far as the open source software is concerned Moodle includes more characteristics, but E-class that is based on Claroline is supported by the Greek University Network. The university community in Greece seems to follow different approaches in implementing course support environments for its courses.

Although the comparison presented in this paper revealed interesting conclusions, we must take into account some other parameters. These are the opinions of the students and instructors that employ the environments. Future extension of this work will include a formative evaluation.

\section{References}

Azuma, J. (1999). Creating educational web sites. IEEE Communications Magazine, 37(3), 109-113.

Ausserhofer, A. (1999). Web-based teaching and learning: a panacea? IEEE Communications Magazine, 37(3), 92-96.

Blackboard official site.

http: / / www.blackboard. com

Claroline official site.

http: //www.claroline.net

Collis, B. (1999). Applications of computer communications in education: an overview. IEEE Communications Magazine, 37(3), 82-86.

Copinga, G., M. Verhaegen and M. van de Ven (2000). Toward a web-based study support environment for teaching. IEEE Control Systems Magazine, 20(4), 8-19.

Das, S., S. Yost and M. Krishnan (1999). Effective use of web-based communication tools in a team-oriented, project-based, multi-disciplinary course. In Proc. 29th ASSE/IEEE Frontiers in Education Conference (FIE'99), San Juan, Puerto Rico 13A2. pp. 14-17.

Edutools.

http: / / www. edutools.info

Kochikar, V., and S. Yegneshwar (2000). Using web-based technologies to support learning needs in a highgrowth, knowledge-based industry. In Proc. 30th ASSE/IEEE Frontiers in Education Conference (FIE 2000). Kansas City, MO, S1D. pp. 7-11.

Margi, C., et al. (2000). An online web course environment and its application. In Proc. 30th ASSE/IEEE Frontiers in Education Conference (FIE 2000). Kansas City, MO, T3D. pp. 1-6. 
McCreanor, P. (2000). Developing a web-enhanced course: a case study. In Proc. 30th ASSE/IEEE Frontiers in Education Conference (FIE 2000). Kansas City, MO, S1B. pp. 18-22.

Moodle official site.

http://moodle.org

Remmers, E., and B. Collis (2000). Didactical activities and strategies in the use of www-based course-support environments: design guidelines for instructors. In J. Bourdeau and R. Heller (Eds.), ED-MEDIA 2000: World Conference on Educational Multimedia. Hypermedia \& Telecommunications, Charlottesville, VA. pp. 898-903.

Ward, M., and D. Newlands (1998). Use of the web in undergraduate teaching. Computers \& Education, 31(2), $171-184$.

Veglis, A. (2000). Design of a web-based interactive computer lab course. In Proc. 10th Mediterranean Electrotechnology Conference (MELECON 2000), Cyprus, Vol. I. pp. 302-305.

Veglis, A. (2002). Web Based Teaching Systems, IEEE Distributed Systems on Line, April 2002.

http://dsonline.computer.org/portal/site/dsonline/menuitem. 9ed3d9924aeb0dcd82ccc6716bbe36ec/index.jsp? \&pName=dso_level1\&path= dsonline/0204/departments\&ile=edu_print.xml\&xsl=article.xsl\&

Veglis, A., and C. Barbargires (2001). A web-based course-support environment. Communications World, Electrical and Computer Engineering Series, 65-69.

Veglis, A., and C. Barbargires (2003). Development and evaluation of a web-based environment for supporting office automation courses in undergraduate journalism and mass communication studies. IEEE Learning Technologies, October.

Veglis, A., and A. Pomportsis (2004). Development and evaluation of a course support environment. Wseas Transactions on Information Science and Applications Issue, 1(1), 133-138.

Yaskin, D., (2001). Blackboard Learning System (Release 6), Product Overview White Paper, Blackboard Inc.

A. Veglis is an associate professor, head of the Media Informatics Lab in the Department of Journalism \& Mass Communication at the Aristotle University of Thessaloniki. He received his BSc in physics, MSc in electronics and communications, and $\mathrm{PhD}$ in computer science, all from Aristotle University. His research interests include information technology in journalism, new media, course support environments, and distance learning. 


\section{Mokomuju aplinku palyginimas: komercinė programinė iranga /versus/ atvirosios programos}

\section{Andreas VEGLIS}

Mokomosios aplinkos yra reikšmingas techninio vystymosi veiksnys, susijęs su kompiuterinemis komunikacijomis, taikomomis švietime. Šiose aplinkose svarbus žiniatinkliui pritaikytos (Web-compliant) vartotojo sąsajos ir žiniatinkliui pritaikytu (Web-compliant) priemonių bei programèlių sąryšis su konkrečia duomenų baze. Straipsnyje lyginamos trys skirtingos mokomosios aplinkos: viena ju komerciné, o kitos dvi - atvirosios. Lyginant atsižvelgiama i i̇vairias šiu programiniu irangų savybès, jos nagrinejjamos tiek iš besimokančiojo, tiek iš dèstančiojo perspektyvos. 